\title{
Pengaruh Penggunaan Hijauan Rawa Fermentasi Terhadap Penampilan Kambing Kacang (Capra hircus)
}

\author{
A. Jaelani, T. Rostini, M. I. Zakir, Jonathan \\ Prodi Peternakan Fakultas Pertanian Universitas Islam Kalimantan MAB \\ Jl. Adhyaksa No. 2 Kayu Tangi Banjarmasin \\ Email : ach jaelaniborneo@yahoo.com
}

\begin{abstract}
ABSTRAK
Penelitian tentang pengaruh penggunaan hijauan rawa fermentasi terhadap penampilan Kambing Kacang telah dilaksanakan di kota Maraban dari Agustus sampai September 2013. Penelitian ini merupakan penelitian eksperimental dengan menggunakan Rancangan Acak Kelompok dengan 3 perlakuan dan 4 kelompok sebagai ulangan $(3 \times 4)$ sehingga diperoleh 12 unit. Perlakuannya adalah K1 (menggunakan 100\% hijauan segar), K2 (menggunakan silase hijauan rawa), K3 (menggunakan hijauan rawa haylage). Bobot badan kambing adalah rata-rata $11-14 \mathrm{~kg}$. Hasil tes ANOVA menunjukkan bahwa penggunaan hijauan rawa fermentasi lebih nyata mempengaruhi konsumsi pakan (570,8 g/ekor/hari), dan berpengaruh nyata pada bobot badan akhir $(16.3 \mathrm{~kg})$ tetapi tidak berpengaruh nyata pada rata-rata pertambahan bobot badan dan konversi pakan. Perlakuan silase dari hijaun rawa dapat meningkatkan konsumsi dan bobot badan akhir kambing kacang.
\end{abstract}

Kata kunci: hijauan rawa, silase, haylage, kambing kacang

Effect of Using Swamp Forages Fermentation to Kacang Goat (Capra hircus)Performance

\section{ABSTRACT}

The study effect of using swamp forages fermentation to Kacang Goat performance was conducted in Marabahan City from August till September 2013. This study was used an experimental method. The design used was a completely blocked design with 3 treatments and 4 Block as replications (3x4) to obtain 12 units. The Treatment are K1 (using 100\% fresh forage), K2 (using silage of swamp forage), K3 (using haylage of swamp forage). The goat was average 11-14 kg body weight.ANOVA test results showed that using of swamp forages fermentation more significantly affect the feed consumption (570.8 g.goat ${ }^{-1} \cdot$ day $\left.^{-1}\right)$, and significantly to final bodyweight (16.3 kg), but did not significantly affect to average daily gain, and feed convertion. Treatment Silage of forage swamp could be raise feed consumption and final body weight of Kacang goat.

Key words: Swamp forage, silage, haylage, Kacang goat

\section{PENDAHULUAN}

Pemenuhan kebutuhan pakan baik dari segi kualitas maupun kuantitas sangat diperlukan karena pakan merupakan salah satu faktor penting dalam menunjang produktifitas ternak kambing kacang. Kondisi ketersediaan hijauan di Indonesia saat ini berfluktuatif, ketika musim hujan, hijauan melimpah, sedangkan pada musim kemarau ketersediaan hijauan berkurang. Hijauan rawa beragam jenisnya, sebagian dari yang telah teridentifikasi ternyata dapat dikonsumsi ternak dan cukup disukai oleh ternak ruminansia. Contoh hijauan rawa yang telah teridentifikasi adalah rumput kumpai minyak (Hymenachne amplexicaulis), rumput kumpai tembaga 
(Hymenachne acutigluma), rumput bento rayap (Leersia hexandra $S W$.), rumput padipadian (Oryza rufipogon), rumput aleman (Echinochloa polystachya), dan rumput kolonjono (Brachiaria muticum), (Mannetje and Jones, 1992). Walaupun demikian ketersediaan hijauan rawa baik rumput maupun leguminosa masih sangat terbatas karena musim, pada saat musim surut hijauan rawa sulit ditemukan. Hijauan rawa alami ini pada umumnya mengandung keterbatasan dalam kandungan proteinnya, seperti yang dinyatakan oleh Martawijaya (1990), rumput alam sangat terbatas kandungan proteinnya yaitu berkisar 4\% dengan kandungan serat kasar yang cukup tinggi.

Kambing kacang merupakan salah satu kambing asli Indonesia yang banyak dipelihara oleh masyarakat di pedesaan. Beberapa keunggulan kambing kacang adalah mudah beradaptasi dengan lingkungan baru terutama didaerah tropis, kambing kacang adalah ternak ruminansia kecil yang efisien dalam mengkonversi rumput menjadi daging, tahan terhadap penyakit, dan reproduksi baik (Devendra dan Burns, 1994).Namun potensi ini belum optimal karena pertumbuhan kambing kacang relatif lambat, untuk itu perlu penerapan pola pemeliharaan ternak kambing yang lebih intensif dengan pemeliharaan ternak dalam waktu singkat dan menggunakan pakan bernutrien tinggidengan pemberian hijauan rawa fermentasi pada kambinguntuk mendapatkan konsumsi pakan serta pertambahan bobot badan yang baik.

Sehubungan dengan kondisi tersebut, maka diperlukan teknologi yang dapat menyediakan pakan ternak secara berkelanjutan dan berkualitas. Beberapa cara pengawetan hijauan untuk menyediakan hijauan sepanjang tahunantara lain: pembuatan silase dan haylage (proses pengawetan hijauan dengan teknologi fermentasi anaerob). Dibandingkan dengan teknologi pengeringan (hay), teknologi fermentasi anaerob lebih sesuai untuk diterapkan dalam penyediaan pakan, kondisi ini dikarenakan, selain produk yang dihasilkan lebih tahan lama, teknologi fermentasi bertujuan untuk meningkatkan daya cerna dan efisiensi pakan serta mensyaratkan kadar air tinggi yang secara alami dimiliki oleh bahan pakan setelah dipanen keadaan ini berdampak pada lebih ekonomisnya teknologi fermentasi.

Tujuan Penelitian adalah untukMengetahui pengaruh penggunaan hijauan rawa fermentasi terhadap penampilan kambing kacang.

\section{MATERI DAN METODA}

\section{Waktu dan Tempat Penelitian}

Penelitian ini dilaksanakandi Kelurahan Barimba Kecamatan Kapuas Hilir Kabupaten Kapuas dan Laboraturium Fakultas Pertanian Uniska, selama 8 minggu dari bulan Agustus sampai dengan September 2013.

\section{Ternak Percobaan}

Kambing kacang sebanyak 12 ekor dengan jenis kelamin jantan, umur 12-14 bulan dengan kisaran bobot badan antara 11 sampai dengan $14 \mathrm{~kg}$. Penentuan umur ternak didasarkan pada kondisi gigi seri kambing yang masih temporer dan dalam keadaan renggang. Kambing tersebut diperoleh dari peternak dari Kapuas dan Banjarbaru.

\section{Kandang}

Kandang yang digunakan pada penelitian ini adalah kandang individual tipe panggung yang disekat dengan ukuran setiap petak kandang untuk kambing kacang 0,7 $\times$ $1 \mathrm{~m}$ dan tinggi $1 \mathrm{~m}$. Adapun bahan rangka dari kayu, lantai bambu dan atap daun rumbia, bahan tersebut diperoleh dari sekitar lokasi penelitian,masing-masing kandang dilengkapi dengan bak pakan memanjang yang terbuat dari kayudan sebuah baskom plastik tempat untuk kambing minum.

\section{Pakan Ternak}

Pakan ternak yang diberikan selama penelitian terdiri dari hijauan rawa 
jeniskumpai minyak (Hymenachne amplexicaulis), rumput kumpai tembaga (Hymenachne acutigluma), rumput padipadian (Oryza rufipogon), hijauan leguminosa yang ada adalah beberasan dan bebatungan (Desmodium scalpe, Cassiathra), yang diperoleh dari lokasi sekitar tempat penelitian. Adapun hijauan rawa fermentasi yaitu silase dan haylage hijauan rawa di peroleh dengan mengacu petunjuk hasil penelitian Rostini (2013).

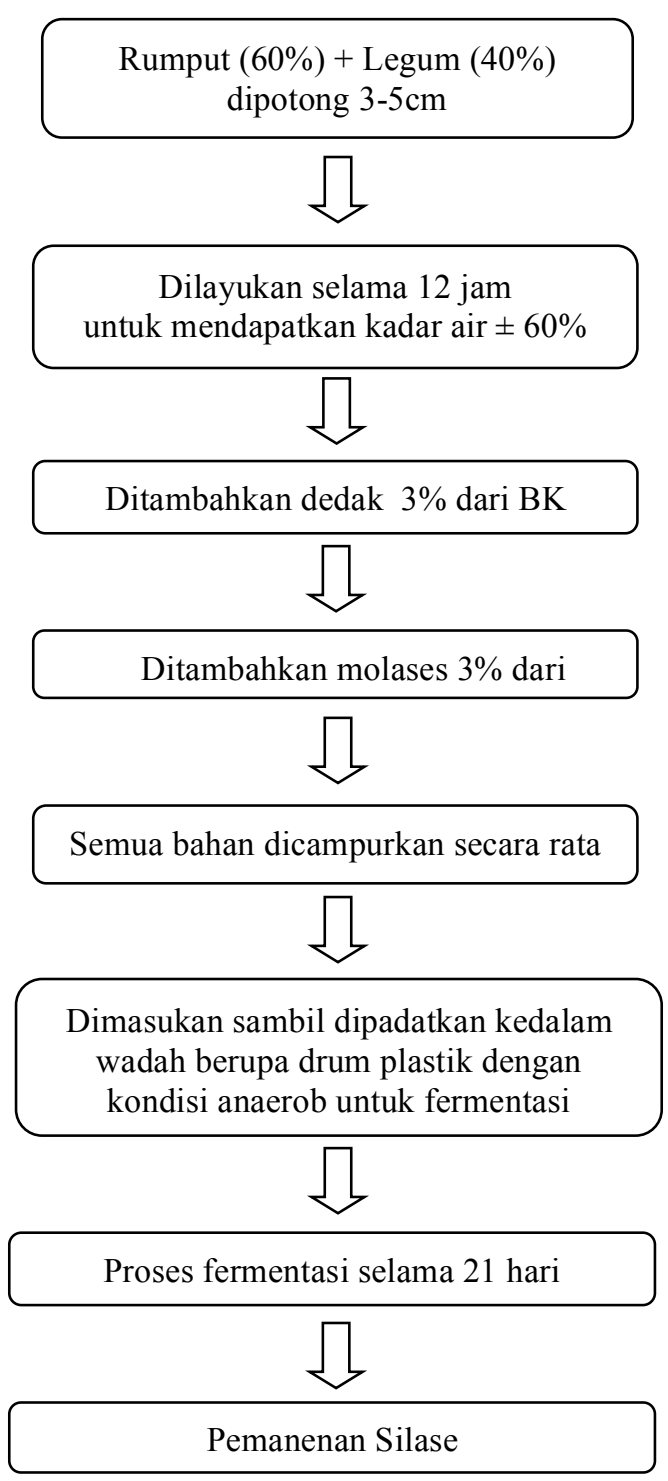

Gambar 1. Diagram alir prosedur pembuatan silase hijauan rawa
Rumput (60\%) + Legum (40\%) dipotong $3-5 \mathrm{~cm}$

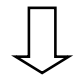

Dilayukan selama 24 jam

untuk mendapatkan kadar air $\pm 30 \%$

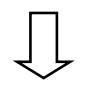

Ditambahkan dedak 3\% dari BK<smiles>C1CCCC1</smiles>

Ditambahkan molases 3\% dari BK

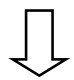

Semua bahan dicampurkan secara rata

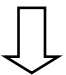

Dimasukan sambil dipadatkan kedalam wadah berupa drum plastik dengan kondisi anaerob untuk fermentasi

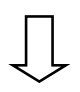

Proses fermentasi selama 21 hari

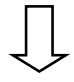

Pemanenan Haylage

Gambar 2. Diagram alir prosedur pembuatan haylage hijauan rawa

Pemberian pakan tersebut dilakukan sesuai perlakuan sebanyak $10 \%$ dari bobot badan dan berdasarkan $3 \%$ dari bobot badan yang dihitung berdasarkan kebutuhan bahan kering. Adapun pemberian hijauan rawa, silase dan haylage hijauan rawa dilakukan dua kali sehari yaitu pukul 08.00 WIB dan 15.00 WIB, pemberian air minum dilakukan secara secara ad libitum. Pembuatan Silase dan Haylage hijauan rawa dilakukan dengan prosedur pada Gambar 1 dan 2. 


\section{Peralatan Penelitian}

Adapun peralatan yang digunakan dalam mendukung kegiatan penelitian ini adalah:

1. Timbangan kapasitas $100 \mathrm{~kg}$ merk Dunlop dengan skala ketelitian $100 \mathrm{~g}$ untuk menimbang ternak, sedangkan untuk menimbang pakan digunakan timbangan elektronik SCA-301, kapasitas maksimal $5 \mathrm{~kg}$ dengan skala ketelitian $\mathrm{d}=1 \mathrm{~g}$.

2. Alat pengukur suhu di kandang merk GEA.

3. Parang dan sabit, untuk memotong hijauan.

4. Tempat pakan dari kayu dan baskom sebagai tempat minum ternak.

5. kompor khusus pemanas suhu kandang yang terbuat dari plat besi.

\section{Metode Penelitian}

Sebelum pelaksanaan penelitian, terlebih dahulu dilakukan pengelompokan ternak berdasarkan bobot badan, kemudian dilakukan pengacakan terhadap kambing sesuai dengan perlakuan yang diberikan. Untuk memudahkan identifikasi kambing penelitian, maka kandang masing-masing diberi label huruf serta nomor.

Rancangan yang digunakan adalah Rancangan Acak Kelompok (RAK) dengan tiga perlakuan (K1, K2, K3), dengan $\mathrm{K} 1$ sebagai kontrol. Masing-masing perlakuan dikelompokan kedalam 3 kelompok bobot badan dengan kisaran 11-14 kg (yang berfungsi sebagai ulangan) dan setiap ulangan terdiri dari 2 ekor kambing Kacang, sehingga kambing yang digunakan dalam penelitian ini sebanyak 18 ekor. Adapun Perlakuannya adalah:

$\mathrm{K} 1=$ Kambing yang diberi $100 \%$ Hijauan Rawa.

$\mathrm{K} 2$ = Kambing yang diberi $100 \%$ Silase Hijauan Rawa.

$\mathrm{K} 3=$ Kambing yang diberi $100 \%$ Haylage Hijauan Rawa.

Kandungan nutrisi bahan pakan penelitian tersaji pada Tabel 1.

\section{Pelaksanaan Penelitian}

Pelaksanaan penelitian dibagi menjadi tiga tahap yaitu:

1. Tahap Persiapan

Pada tahap persiapan ternak percobaan dibiasakan terhadap lingkungan kandang dan pakan, serta menimbang kambing kacang untuk mengetahui bobot badan awal.Adaptasi dilakukan selama dua minggu, adapun tujuan dari tahap pendahuluan (adaptasi) adalah, untuk membiasakan ternak dengan keadaan lingkungan dan pakan yang baru (pakan yang diberikan pada waktu penelitian) serta untuk menghilangkan pengaruh pakan sebelumnnya.

Sebelum proses penelitian pemeliharaan kambing, kandang dan peralatan dibersihkan dan disucihamakan. Kandang dibersihkan dengan menggunakan Rodalon dengan dosis $15 \mathrm{ml} / 10$ liter air, beserta tempat pakan dan minum. Persiapan kambing yang digunakan dalam penelitian ini ditimbang terlebih dahulu untuk mengetahui bobot awalnya dan dipilih kambing kacang dengan bobot badan yang relatif sama (homogen).

Kambing kacang sebelum digunakan untuk penelitian diberi obat cacing merk (merk Cavita) secara oral dengan dosis $1 \mathrm{ml}$ per $1,5 \mathrm{~kg}$ bobot badan untuk menghilangkan parasit dalam saluran pencernaan.

2. Tahap Pemeliharaan

Tahap pemeliharaan dilakukan dengan pemberian pakan sesuai dengan perlakuan dalam penelitian. Adapun pemberian hijauan rawa, silase dan haylage hijauan rawa dilakukan dua kali sehari yaitu pukul 08.00 WIB dan 15.00 WIB, pemberian air minum dilakukan secara secara ad libitum

\section{Tahap Koleksi Data}

Tahap koleksi data dilakukan selama 8 minggu dengan pemberian pakan sesuai dengan perlakuan dalam penelitian. Kegiatan koleksi data yaitu menimbang bobot badan kambing kacang, dilakukan setiap dua minggu sekali dan setiap hari 
Tabel 1. Kandungan Nutrisi Bahan Pakan Penelitian

\begin{tabular}{lccc}
\hline \multirow{2}{*}{ Kandungan Nutrisi } & \multicolumn{3}{c}{ Jenis Pakan } \\
\cline { 2 - 4 } & Hijauan Rawa Segar (\%) & Silase (\%) & Haylage (\%) \\
\hline Bahan Kering & 94.05 & 91.19 & 92.95 \\
Bahan Organik & 88.57 & 88.20 & 88.46 \\
Protein Kasar & 12.1 & 14.02 & 14.25 \\
Lemak Kasar & 6.11 & 8.13 & 7.79 \\
Kadar Abu & 6.37 & 6.87 & 7.31 \\
Serat Kasar & 15.23 & 13.81 & 14.52 \\
Bet-N & 60.19 & 57.17 & 56.13 \\
TDN & 74.3 & 74.48 & 75.38 \\
\hline
\end{tabular}

Keterangan : Hasil Lab. Nutrisi dan Teknologi Pakan Fapet IPB (2013)

Tabel 2. Hasil Penelitian Pengaruh Penggunaan Hijauan Rawa Fermentasi Terhadap Penampilan Kambing Kacang

\begin{tabular}{lccc}
\hline \multirow{2}{*}{ Parameter } & \multicolumn{3}{c}{ Perlakuan } \\
\cline { 2 - 4 } & $534.15^{\mathrm{a}}$ & $570.80^{\mathrm{a}}$ & $\mathrm{K} 3$ \\
\hline Konsumsi pakan (BK) (g/ekor/hari) & $15.13^{\mathrm{a}}$ & $16.13^{\mathrm{b}}$ & $15.13^{\mathrm{b}}$ \\
Bobot badan akhir (kg) & 50.00 & 61.9 & 48.82 \\
Pertambahan bobot badan Harian & 0.09 & 0.11 & 0.12 \\
(g/ekor/hari) & & & \\
Efisiensi pakan &
\end{tabular}

\section{Keterangan:}

$\mathrm{K} 1=$ Kambing Kacang yang diberi 100\% Hijauan Rawa.

K2 = Kambing Kacang yang diberi 100\% Silase Hijauan Rawa.

K3 = Kambing Kacang yang diberi 100\% Haylage Hijauan Rawa.

*Huruf superskrip yang berbeda pada baris rata-rata menunjukanberpengaruh nyata pada $\operatorname{taraf}(\mathrm{P}<0,05)$

menimbang pakan yang diberikan dan mencatat konsumsi serta pakan yang tersisa.

\section{Parameter yang Diamati}

\section{Konsumsi Pakan (dalam bahan kering)}

Konsumsi pakan harian (g/ekor/hari) dihitung berdasarkan selisih antara jumlah pakan yang diberikan dengan jumlah pakan yang tersisa setiap hari selama penelitian.

\section{Bobot Badan Akhir (kg/ekor)}

Diperoleh dari penimbangan ternak kambing pada akhir penelitian.

\section{Pertambahan Bobot Badan Harian (g/ekor/hari)}

Pertambahan bobot badan harian diperoleh dari bobot badan akhir dikurangi dengan bobot badan awal dibagi dengan lama waktu pemeliharaan.

\section{Efisiensi Penggunaan Pakan}

Efisiensi pakan dihitung dengan cara membagi angka rata-rata pertambahan bobotbadan harian per gram/ekor/hari dengan angka rata-rata konsumsi pakan dalam bahan kering.

\section{Analisis Data}

Data yang diperoleh dianalisis denganmenggunakan analisis ragam sesuai dengan rancangan yang digunakan. Model linier analisis keragaman pada penelitian ini adalah:

Keterangan:

$$
Y_{i j}=\mu+\tau i+\beta j+\varepsilon_{i j}
$$

$\mathrm{Y}_{\mathrm{ij}}=$ nilai pengamatan pada perlakuan ke-i, dan kelompok ke-j

$\mu=$ nilai tengah populasi

$\tau \mathrm{i}=$ pengaruh perlakuan ke- $\mathrm{i}$

$\beta \mathrm{j}=$ pengaruh kelompok ke $-\mathrm{j}$

$\varepsilon_{\mathrm{ij}}=$ pengaruh galatpada perlakuan ke-i kelompok ke-j 
Apabila terdapat pengaruh nyata maka dilanjutkan dengan uji wilayah berganda Duncan (DMRT) menurut (Steel dan Torrie, 1993).

\section{HASIL DAN PEMBAHASAN}

Berdasarkan hasil analisis ragam dan Uji wilayah Berganda Duncan pada semua peubah penelitian, disajikan pada Tabel 2.

\section{Konsumsi Pakan}

Hasil analisis ragam menunjukkan bahwa penggunaan hijauan rawa fermentasi berpengaruh sangat nyata terhadap konsumsi bahan kering pakan kambing kacang. Pada Tabel 2 menunjukkan bahwa rata-rata konsumsi pada perlakuan K1 (534,15 g/ekor/hari) dan K2 (570,80 g/ekor/hari) berbeda nyata dengan K3 yang jumlah ratarata konsumsi pakan yang paling rendah (406,73 g/ekor/hari). Adapun perlakuan jenis pakan silase hijauan rawa K2 menghasilkan konsumsi pakan yang tertinggi $(570,80$ g/ekor/hari).

Peningkatan konsumsi pakan pada perlakuan silase hijauan rawa, hal ini diduga karena tingkat kesukaan ternak kambing terhadaptekstur, bau, rasa, dan suhu dari pakan yang diberikan, mempengaruhi tingkat konsumsi. Hal ini sesuai dengan pendapat Sofyan dan Febrisiantosa (2007), bahwa silase memiliki sifat bau harum dan asam sehingga lebih disukai ternak (palatable).

Dengan kandungan serat kasar yang lebih rendah $(13,81 \%)$, jika dibandingkan dengan hijauan segar $(15,23 \%)$ dan haylage $(14,52 \%)$ sehingga konsumsi silase hijauan rawa lebih tinggi dari hijauan rawa segar sebagai kontrol maupun haylage. Parakkasi (1995), mengemukakan bahwa tingkat konsumsi bahan kering dipengaruhi oleh sifat fisik dan komposisi kimia makanan yang dapat memengaruhi kecernaan yang selanjutnya mempengaruhi konsumsi.

Grafik pengaruh penggunaan hijauan rawa fermentasi terhadap konsumsi pakan dalam bahan kering disajikan pada Gambar
3, yang menunjukkan bahwa konsumsi perlakuan K2 silase hijauan rawa $(570,80$ g/ekor/hari) paling tinggi dari K1 hijauan rawa segar $(534,15 \mathrm{~g} /$ ekor/hari) dan $\mathrm{K} 3$ haylage (406,73 g/ekor/hari).

\section{Bobot Badan Akhir}

Hasil analisis ragam menunjukkan bahwa penggunaan hijauan rawa fermentasi berpengaruh sangat nyata terhadap bobot badan akhir kambing kacang. Hasil uji Duncan, yaitu rata-rata perlakuan pada K2 silase hijauan rawa $(16,13 \mathrm{~kg} / \mathrm{ekor})$ berpengaruh nyata pada taraf $(\mathrm{P}<0,05)$ dengan $\mathrm{K} 1$ hijauan rawa segar $(15,13$ $\mathrm{kg}$ /ekor) dan K3 haylage hijauan rawa dengan bobot badan akhir yang paling rendah $(15,10 \mathrm{~kg} / \mathrm{ekor})$, Hal ini diduga karena ada hubungannya antara tingkat konsumsi pakan pada perlakuan K3.

Hasil rata-rata konsumsi pakan dalam bahan kering pada Tabel 2 menunjukan perlakuan K3 (406,73 g/ekor/hari) lebih rendah dari K1dan K2, sehingga ini juga berpengaruh terhadap perolehan bobot badan akhir. Hal ini sesuai dengan pendapat Martawijaya (1999), yaitu pertambahan bobot hidup ternakerat kaitannya dengan konsumsi pakan. Kartadisastra (1997), mengemukakan bahwa bobot tubuh ternak senantiasa berbanding lurus dengan tingkat konsumsi pakannya. Makin tinggi bobot tubuhnya, maka semakin tinggi pula tingkat konsumsi terhadap pakan dan bobot badan dapat diketahui dengan penimbangan (Kartadisastra, 1997).

Grafik pengaruh penggunaan hijauan rawa fermentasi terhadap bobot badan akhir disajikan pada Gambar 4, yang menunjukkan bahwa rata-rata bobot badan akhir perlakuan K3 haylage hijauan rawa $(15,10 \mathrm{~kg} /$ ekor $)$ paling rendah dari $\mathrm{K} 1$ hijauan rawa segar $(15,13 \mathrm{~kg} / \mathrm{ekor})$. Adapun perolehan bobot badan akhir tertinggi adalah pada perlakuan K2 silase hijauan rawa (16,13 kg/ekor).

\section{Pertambahan Bobot Badan Harian}


Hasil analisis ragam menunjukkan bahwa penggunaan hijauan rawa fermentasi tidak berpengaruh nyata terhadap pertambahan bobot badan harian pada kambing kacang. Berdasarkan hasil uji Anova menunjukkan bahwa pertambahan berat badan harian kambing kacang tertinggi yaitu pada perlakuan yang diberi jenis pakan K2 silase hijauan rawa (61,900 g/ekor/hari), $\mathrm{K} 1$ hijauan rawa tanpa fermentasi $(50,00$ $\mathrm{g} / \mathrm{ek} / \mathrm{hr}$ ), dan terendah pada perlakuan K3 haylage $(48,82 \mathrm{~g} / \mathrm{ekor} / \mathrm{hari})$. Hal ini diduga karena pertambahan bobot badan kambing, erat kaitannya dengan konsumsi pakan. Telah diuraikan di atas bahwa konsumsi pakan dalam bahan kering antar perlakuan ransum K1 (534,15 g/ekor/hari), K2 (570,80 gram/ekor/hari) dan K3 (406,73 g/ekor/hari), secara statistik berpengaruh sangat nyata. Dari konsumsi ransum tersebut, kambing dengan perlakuan ransum K2 $(61,90$ g/ekor/hari) menghasilkan pertambahan bobot badan harian tertinggi, sedangkan terendah pada perlakuan ransum K3 $(48,82$ g/ekor/hari), dengan demikian teknologi pakan dalam bentuk silase hijauan rawa masih dapat menghasilkan pertambahan bobot badan yang baik.

Hasil tersebut sesuai menurut Tilman et al. (1983), bahwa semakin tinggi konsumsi bahan kering maka akan semakin banyak zat-zat makanan yang dikonsumsi yang akan digunakan untuk pertumbuhan dan produksi sehingga berpengaruh pada berat badan.

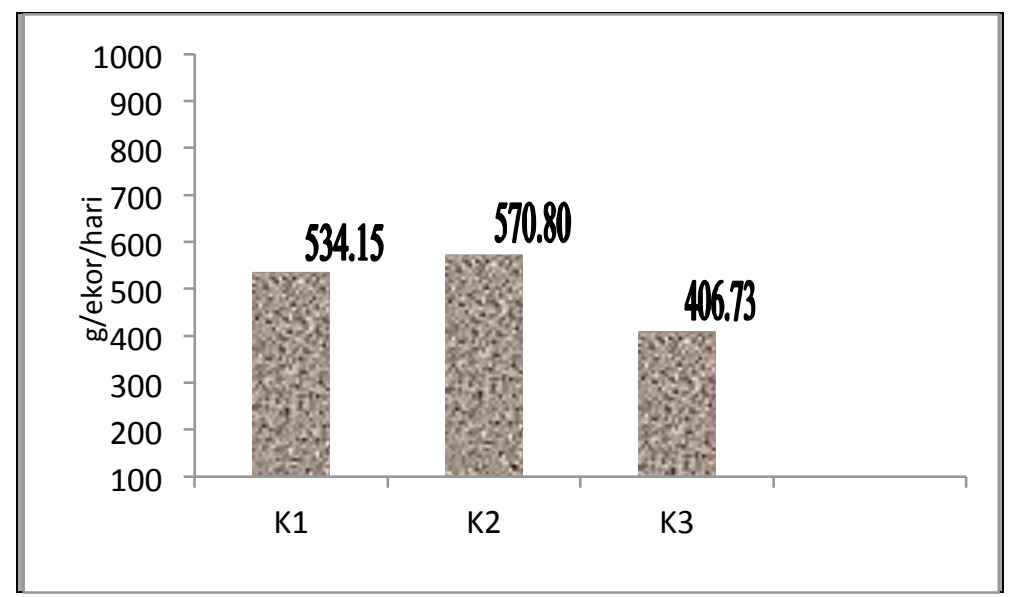

Gambar 3. Pengaruh penggunaan hijauan rawa fermentasi terhadap konsumsi pakan dalam bahan kering.

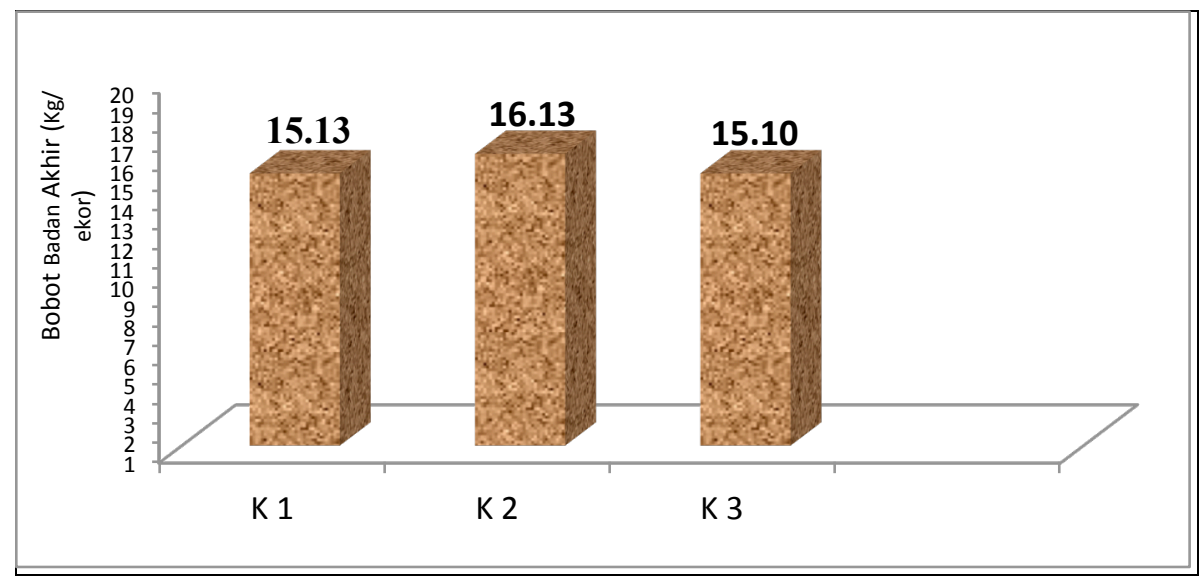

Gambar 4. Pengaruh penggunaan hijauan rawa fermentasi terhadap bobot badan akhir kambing kacang (kg/ekor) 
Grafik pengaruh penggunaan hijauan rawa fermentasi terhadap pertambahan bobot badan harian disajikan pada Gambar 3, yang menunjukkan bahwa rata-rata pertambahan bobot badan harian perlakuan K3 haylage hijauan rawa $(48,82 \mathrm{~g} / \mathrm{ekor} / \mathrm{hari})$ paling rendah dari $\mathrm{K} 1$ hijauan rawa segar $(50,00$ g/ekor/hari). Adapun pertambahan bobot badan harian tertinggi adalah pada perlakuan K2 silase hijauan rawa (61,90 g/ekor/hari).

\section{Efisiensi Penggunaan Pakan}

Hasil perhitungan pada pengaruh perlakuan hijauan rawa fermentasi terhadap efesiensi penggunaan pakan pada kambing kacang selama penelitian disajikan pada Gambar 6.
Hasil analisis ragam menunjukkan bahwa penggunaan hijauan rawa fermentasi tidak berpengaruh nyata terhadap efisiensi penggunaan pakan pada kambing kacang. Rataan efisiensi pakan pada perlakuan $\mathrm{K} 1$, K2 dan K3 berturut-turut 0,09; 0,11 dan 0,12. Efisiensi pakan yang tinggi menunjukkan penampilan yang lebih baik. Kondisi ini dikarenakan, semakin tinggi nilai efisiensi pakan, maka pakan yang dikonsumsi oleh kambing tersebut lebih sedikit, namun menghasilkan pertambahan bobot badan yang tinggi.

Efisiensi pakan diukur dari unit pertambahan bobot badan per satuan waktunya dibagi dengan jumlah pakan dalam bahan kering yang dikonsumsi.

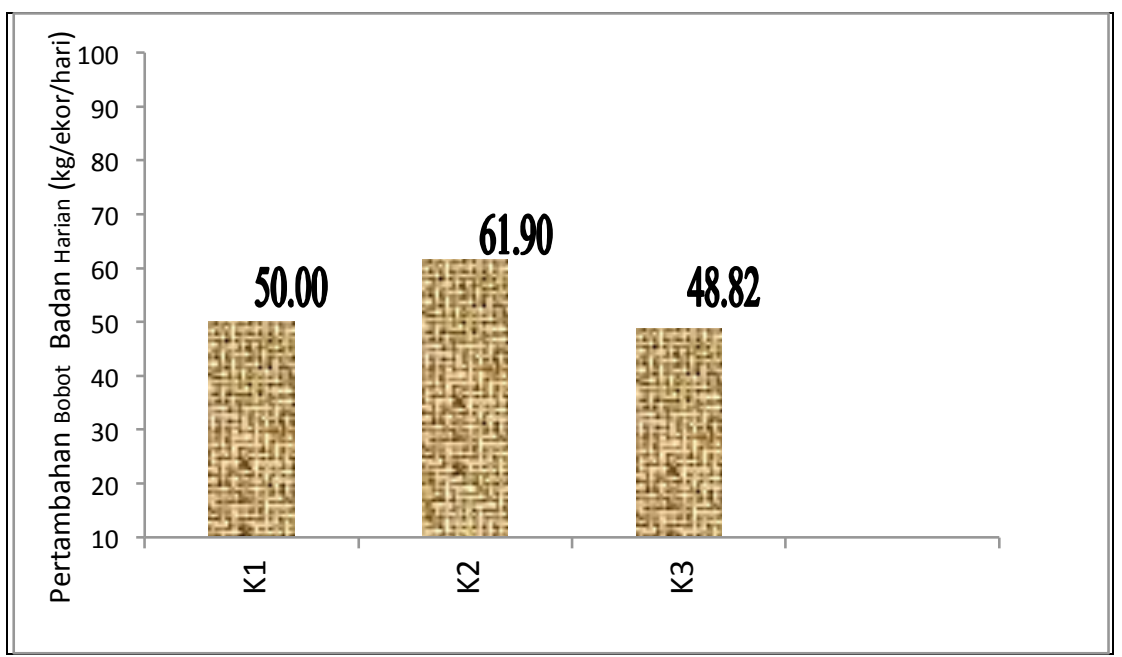

Gambar 5. Pengaruh penggunaan hijauan rawa fermentasi terhadap pertambahan bobot badan harian (g/ekor/hari).

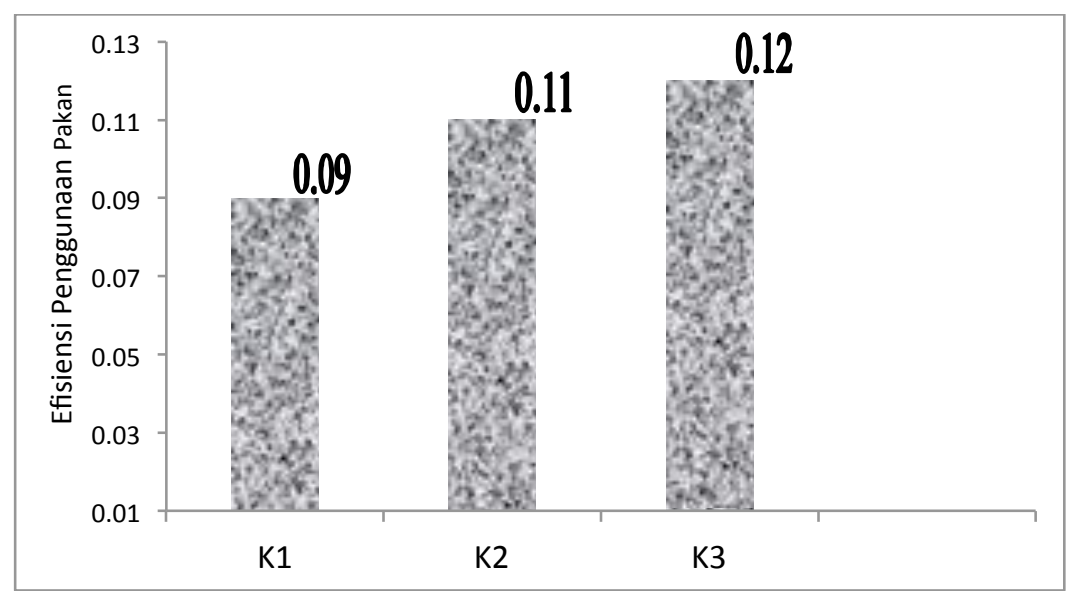

Gambar 6. Pengaruh penggunaan hijauan rawa fermentasi terhadap efisiensi penggunaan pakan 
Penelitian ini menghasilkan rata-rata efisiensi pakan 0,11 Hasil tersebut sesuai dengan penelitian terdahulu 0,11 pada kambing Beorka yang dilaporkan Simanahuruk dan Sirait (2010).

Efisiensi pakan tertinggi khususnya pada perlakuan haylage hijauan rawa K3 $(0,12)$, diduga dipengaruhi oleh tingginya kandungan energi dalam pakan tersebut, hal ini selaras dengan pendapat Cheeke (1987), menyatakan bahwa kandungan energi ransum mempengaruhi efisiensi penggunaan ransum yakni dengan semakin tinggi kandungan energi dalam ransum akan menurunkan konversi pakan dan meningkatkan efisiensi pakan.

Grafik pengaruh penggunaan hijauan rawa fermentasi terhadap efisiensi penggunaan pakan disajikan pada Gambar 6 . Efisiensi penggunaan pakan pada perlakuan $\mathrm{K} 3$ haylage hijauan rawa $(0,12)$ lebih efisien dari pada perlakuan $\mathrm{K} 2$ silase hijauan rawa $(0,11)$ dan perlakuan $\mathrm{K} 1$ hijauan rawa $(0,09)$.

\section{SIMPULAN}

Berdasarkan hasil dan pembahasan maka disimpulkan bahwa:

1. Perlakuan silase hijauan rawa fermentasi pada kambing kacang, berpengaruh sangat nyata terhadap konsumsi pakan dan berpengaruh nyata terhadap berat badan akhir sedangkan terhadap pertambahan bobot badan harian dan efisiensi pakan tidak berpengaruh nyata.

2. Penggunaan hijauan rawa fermentasi dalam bentuk silase hanya dapat meningkatkan konsumsi pakan dalam bahan kering, berat badan akhir, namun tidak terhadap pertambahan bobot badan harian. Adapun haylage untuk efisiensi penggunaan pakan terbaik kambing kacang.

\section{DAFTAR PUSTAKA}

Adriani. 2009. Bobot Badan dan Kecernaan Nutrien Pada Kambing Peranakan Etawah Sebagai Respon Pemberian Konsentrasi Seng yang Berbeda Dalam
Pakan. J. Ilmu-Ilmu Peternakan Ed. Khusus Seminar Nasional. Nov. 2005. 82-90.

Anggorodi, R. 1990. Ilmu Makanan Ternak Umum. PT. Gramedia, Jakarta.

Badjoeri, M. dan Lukman 2002. Pemanfaatan Tumbuhan Kumpai dari Danau Semayang Sebagai Pakan Sapi. Jurnal Tropic Animal Agriculture, 27 (2):125133.

Devendra, R. J. dan Burns. 1994. Produksi Kambing di Daerah Tropis. Universitas Udayana. Bali.

Dilaga, S. H. 2006. Kontribusi Potensial Padang Rumput Sebagai Wadah dan Sumber Pakan Kerbau di Sumbawa. Proseding Lokakarya Nasional: Usaha Ternak Kerbau Mendukung Program Kecukupan Daging Sapi. Hal. 227-233

Ella, A. D. Pasambe dan Yusuf. 2001 Pengaruh Perbaikan Pakan Terhadap Peningkatan Pertumbuhan Kambing Lepas Sapih Puslitbang. Bogor.

Fahriani, A. dan Eviyati. 2008. Potensi Rumput Rawa Sebagai Pakan Ruminansia : Produksi, Daya Tampung dan Kandungan Fraksi Seratnya. Jurnal Indonesia Tropik Animal Agriculture, 33 (4) Desember.

Kartadisastra, H. R. 1997. Penyediaan dan Pengelolaan Pakan Ternak Ruminansia. Kanisius. Yogyakarta

Lendrawati. 2008. Kualitas Fermentasi dan Nutrisi Silase Ransum Komplit Berbasis Hasil Samping Jagung, Sawit, dan Ubi Kayu. Tesis. Bogor.

McDonald, P., A. R. Henderson, and S. J. E. Heron. 1991. The Biochemistry of Silage. edisi ke-2. Marlow: Chalcombe.

Mannetje, L. T. 1992. Forage. Proses Foundation. Bogor. Indonesia

Martawidjaja, M., Kuswandi dan B. Setiadi. 2001. Pengaruh Tingkat Protein Ransum Terhadap Penampilan Kambing Persilangan Boer dan Kacang. Proc. Seminar Nasional Teknologi Peternakan dan Veteriner. Puslitbang Pertanian. Bogor.

Noor, M. I. L. 2007 Pengembangan Lahan Rawa Berkelanjutan Untuk Mendukung Ketahan Pangan Nasional. Badan Litbang Pertanian.

NRC.1981. Nutrient Requirements of Goats: Angora, Dairy, and Meat Goats in Temperate and Tropical Countreis. 
Nutrient Requirements of Domestic Animals. No. 15. National Academy Sei, Washington.D.C.

Parakkasi, A. 1999. Ilmu Nutrisi dan Makanan Ternak. UI Press, Jakarta.

Rohaeni, E.S., I. S. Danu, dan A. Subhan. Profil Usaha Ternak Kambing di Lahan Pasang Surut Kalimantan Selatan.Lokakarya Nasional Kambing Potong. Balai Besar Teknologi Pertanian Kalimantan Selatan. 5-170.

Schroeder, J. W. 2004. Silage Fermentation and Preservation. Extension Dairy Speciaslist. AS-1254. www.ext.nodak.edu/extpubs/ansci/dairy/ as $1254 \mathrm{w}$. htm. [June 2013].

Setiadi. 1997. Penelitian Ternak Kambing dan Domba di Pedesaan. Puslitbang Peternakan. Bogor.

Soenardjo, Setiawati dan R. Mulyono. 1997. Usaha Peningkatan Kesuburan Ternak Kambing Bentuk Pellet. Laporan Bapeda Kabupaten Tegal.

Siregar, S. B. 1996. Pengawetan Pakan Ternak. Jakarta: Penebar Swadaya.

Steel, R. G. D. and J. H. Torrie. 1993. Prinsip dan Prosedur Statistik. Ed ke-2.
Sumantri B, Penerjemah. Jakarta: Gramedia Pustaka Utama. Terjemahan dari: The Principle and Procedure of Statistics.

Sofyan A. dan A. Febrisiantosa. 2007. Pakan Ternak Dengan Silase Komplit. UPT.BPPTK -LIPI, Yogyakarta. Majalah INOVASI Edisi 5 Desember.

Tillman, A. D., H. Hartadi, R. Reksohadiprodjo, S. Prawirokusumo, dan S. Lebdosoekojo. 1983. Ilmu Makanan Ternak Dasar. Fakultas Peternakan. Gajah Mada University Press, Yogyakarta.

Wahyudi. 2006. Pengaruh Substitusi Konsentrat Dengan Campuran Ampas Brem dan Onggok Dalam Ransum Terhadap Performan Domba Lokal Jantan. Universitas Sebelas Maret. Surakarta.

Woolford, M. K. 1984. The Silage Fermentation. New York: Marcel Dekker Inc.

Simanahuruk, dan H. Sirait. 2008. Penggunaan Tape Kulit Kakao Sebagai Pakan Kambing Sedang Tumbuh. Loka Penelitian Kambing Potong Sei Putih. Sumatera Utara. 